\title{
Alicyclobacillus pohliae sp. nov., a thermophilic, endospore-forming bacterium isolated from geothermal soil of the north-west slope of Mount Melbourne (Antarctica)
}

Correspondence
Laura Marri
marri@unisi.it

\author{
Tatiana Imperio, ${ }^{1}$ Carlo Vitii ${ }^{2}$ and Laura Marri ${ }^{1}$
}

\author{
${ }^{1}$ Dipartimento di Biologia Evolutiva, Università degli Studi di Siena, Via A. Moro 2, 53100 Siena, \\ Italy \\ ${ }^{2}$ Dipartimento di Biotecnologie Agrarie, Sezione di Microbiologia, Università degli Studi di Firenze, \\ Piazzale delle Cascine 24, 50144 Firenze, Italy
}

\begin{abstract}
Gram-positive, rod-shaped, endospore-forming, thermophilic bacteria were isolated from a geothermal soil collected on the north-west slope of Mount Melbourne in Antarctica. They grew aerobically at $42-60{ }^{\circ} \mathrm{C}$ (optimum $55^{\circ} \mathrm{C}$ ) and at $\mathrm{pH} 4.5-7.5$ (optimum pH 5.5). Phylogenetic analysis of $16 \mathrm{~S}$ rRNA gene sequences showed that these isolates were related most closely to the type strain of Alicyclobacillus pomorum ( $91 \%$ similarity). Growth occurred in the presence of ferrous iron at micromolar concentrations and acid was produced from various sugars.

Iso-branched fatty acids $\mathrm{C}_{15: 0}(45.56 \%)$ and $\mathrm{C}_{17: 0}(35.81 \%)$ were the most abundant cellular fatty acids. The DNA G $+\mathrm{C}$ content was $55.1 \mathrm{~mol} \%$. On the basis of phenotypic and phylogenetic characteristics, it is concluded that these strains represent a novel species of the genus Alicyclobacillus, for which the name Alicyclobacillus pohliae sp. nov. is proposed. The type strain is $\mathrm{MP}^{\top}\left(=\mathrm{CIP} 109385^{\top}=\mathrm{NCIMB} 14276^{\top}\right)$.
\end{abstract}

Members of the genus Alicyclobacillus are heterotrophic, Gram-positive, endospore-forming organisms which inhabit mostly acidic geothermal environments. The genus Alicyclobacillus was first described by Wisotzkey et al. (1992) and the description has subsequently been emended based on newly obtained data (Goto et al., 2003; Karavaiko et al., 2005). At the time of writing, the genus comprises 17 recognized species: Alicyclobacillus acidocaldarius, A. acidoterrestris (Wisotzkey et al., 1992), A. hesperidum (Albuquerque et al., 2000), A. acidiphilus (Matsubara et al., 2002), A. sendaiensis (Tsuruoka et al., 2003), A. vulcanalis (Simbahan et al., 2004), A. tolerans, A. disulfidooxidans (Karavaiko et al., 2005), A. cycloheptanicus (Deinhard et al., 1987), A. herbarius (Goto et al., 2002), A. pomorum (Goto et al., 2003), A. contaminans, A. fastidiosus, A. kakegawensis, A. macrosporangiidus, A. sacchari and A. shizuokensis (Goto et al., 2007). Moreover, three Japanese strains and two isolated from the island of São Miguel in the Azores were denoted as representing two genomic species of Alicyclobacillus based on $16 \mathrm{~S}$ rRNA gene sequence analysis and DNA-DNA hybridization assays (Hiraishi et al., 1997; Albuquerque et al., 2000). In addition, a novel subspecies of $A$. acidocaldarius, subsp.

The GenBank/EMBL/DDBJ accession numbers for the 16S rRNA gene sequences of strains MP1, MP2, MP3 and MP4 ${ }^{\top}$ are AJ607429, AJ607430, AJ607431 and AJ564766, respectively. ritmannii, was isolated from a geothermal site in Antarctica (Nicolaus et al., 1998). Although continental Antarctica is largely ice-bound and supports only sparse growth of terrestrial life, it possesses a small number of sites where the ground is warmed by geothermal sources and is supplied with moisture from the condensation of steam emissions (Bargagli et al., 2004). Novel thermophilic species ascribed to the genera Bacillus, Brevibacillus, Aneurinibacillus and Anoxybacillus have recently been isolated from Antarctic geothermal grounds (Nicolaus et al., 1996; Logan et al., 2000; Allan et al., 2005; Poli et al., 2006).

In the present study, we describe a novel thermophilic bacterium isolated from warm soils collected in the immediate vicinity of a steam vent on the north-west slope of Mount Melbourne, northern Victoria Land, continental Antarctica (74 20.994' S $164^{\circ} 39.792^{\prime}$ E, 2498 m altitude) (Bargagli et al., 2004). Brevibacillus levickii is the only novel species previously recovered from the north-west slope of Mt Melbourne despite repeated soil sampling on separate occasions followed by enrichment and isolation at different times in the laboratory (Allan et al., 2005). In February 2002, four soil samples were collected along a thermal gradient ranging from 25 to $43{ }^{\circ} \mathrm{C}$ in the vicinity of a small area $\left(100 \mathrm{~cm}^{2}\right)$ colonized by shoots of the moss Pohlia nutans (Bargagli et al., 2004). Analytical determinations of chemical properties of soil water extracts showed $\mathrm{pH}$ values ranging 
from 5.46 to 5.71 and relatively higher concentrations of sodium, iron and manganese when compared with chemical characteristics of other geothermal sites in Victoria Land. In particular, the iron concentration ranged from 0.94 to $1.22 \mu \mathrm{g} \mathrm{g}^{-1}$ (Bargagli et al., 2004). After incubation in DSMZ medium $259\left(\mathrm{l}^{-1}: 3.5 \mathrm{~g} \mathrm{Na}_{2} \mathrm{HPO}_{4} .12 \mathrm{H}_{2} \mathrm{O}, 1.0 \mathrm{~g}\right.$ $\mathrm{K}_{2} \mathrm{HPO}_{4}, 0.03 \mathrm{~g} \mathrm{MgSO}_{4} .7 \mathrm{H}_{2} \mathrm{O}, 0.5 \mathrm{~g} \mathrm{NH} 4 \mathrm{Cl}, 4.0 \mathrm{~g}$ yeast extract, $\mathrm{pH}$ 6.5) at $55{ }^{\circ} \mathrm{C}$, all four samples yielded positive cultures. Subcultivation, carried out on tryptone soy agar (TSA; Oxoid) plus $250 \mu \mathrm{M} \mathrm{Fe} \mathrm{SO}_{4} \cdot 7 \mathrm{H}_{2} \mathrm{O}$ (TSA-Fe) at $55{ }^{\circ} \mathrm{C}$, allowed the isolation of four thermophilic strains, designated MP1, MP2, MP3 and $\mathrm{MP}^{\mathrm{T}}$ (Bargagli et al., 2004). Cultures were further propagated on FeP liquid medium $\left[1^{-1}: 5.0 \mathrm{~g}\right.$ tryptone (Difco), $0.5 \mathrm{~g}$ D-glucose, $0.1 \mathrm{~g}$ $\left.\left(\mathrm{NH}_{4}\right)_{2} \mathrm{SO}_{4}, 0.1 \mathrm{~g} \mathrm{FeSO}_{4} .7 \mathrm{H}_{2} \mathrm{O}\right]$, BAM basal salts medium (Deinhard et al., 1987) and/or DSMZ medium 259, all amended with $250 \mu \mathrm{M} \mathrm{Fe}{ }_{2} \mathrm{SO}_{4}$. $7 \mathrm{H}_{2} \mathrm{O}$. In order to establish the requirement for mineral substrates for growth, DSMZ medium 259 , containing 0.01 or 0.1 g yeast extract $1^{-1}$, was supplemented with $250 \mu \mathrm{M} \quad \mathrm{Fe}_{2} \mathrm{SO}_{4} .7 \mathrm{H}_{2} \mathrm{O}, \mathrm{FeCl}_{3}$, $\mathrm{CaCl}_{2} \cdot 2 \mathrm{H}_{2} \mathrm{O}, \mathrm{MgSO}_{4} \cdot 7 \mathrm{H}_{2} \mathrm{O}$ or $\mathrm{Na}_{2} \mathrm{O}_{3} \mathrm{~S}$, or $0.15 \%$ elemental sulfur $\left(\mathrm{S}^{0}\right)$. Growth in liquid media was monitored by measuring the optical density at $570 \mathrm{~nm}$ (Ultrospec 2100 UV-VIS spectrophotometer; Amersham Biosciences). The temperature range for growth was determined by incubating the four isolates at temperatures ranging from 25 to $70{ }^{\circ} \mathrm{C}$. The $\mathrm{pH}$ range for growth was determined in $\mathrm{FeP}$ medium and modified DSMZ medium 259 with $\mathrm{pH}$ adjusted by using $1 \mathrm{M} \mathrm{H}_{2} \mathrm{SO}_{4}$. All pH measurements were made at room temperature. Anaerobic growth was tested in triplicate by spreading each strain on FeP agar (1.5\% Bacto agar; Difco). Plates were placed in a GENbag Anaer chamber (bioMérieux) and incubated for 1 week $\left(\mathrm{O}_{2}<0.1 \%\right.$ after 2-5 h). For studies of heat resistance, 1-week-old colonies were resuspended in fresh liquid medium and exposed to temperatures of 80 or $100{ }^{\circ} \mathrm{C}$ for $10 \mathrm{~min}$. Aliquots were then plated on $\mathrm{FeP}$ agar and survival was measured based on the number of colonies formed after $24-48 \mathrm{~h}$ incubation at $55{ }^{\circ} \mathrm{C}$. After growth on TSA-Fe, colony morphology was observed under a stereomicroscope. Vegetative cells and sporangial morphologies were observed visually by brightfield light microscopy and phase-contrast microscopy, respectively. Gram determination was carried out either by staining (Gram stain kit; Medical Chemical) or a chemical method (Powers, 1995). Catalase and oxidase activities were determined according to Smibert \& Krieg (1981). Sensitivity of the four isolates to ampicillin, chloramphenicol, tetracycline, gentamicin, penicillin G, bacitracin, erythromycin, kanamycin and streptomycin was tested on $\mathrm{FeP}$ agar. Acidification was examined with the API $50 \mathrm{CH}$ test system (bioMérieux) essentially as described by Albuquerque et al. (2000) at the optimum growth temperature. Acidification of the medium was monitored every 2 days for 10 days. All tests were repeated in triplicate. The ability to oxidize different carbon sources was examined by using Biolog GN and GP microplates. Cell suspensions, after growth on TSA$\mathrm{Fe}$, were prepared by following the manufacturer's instructions and then used to inoculate the wells of Biolog microtitre plates. Microplates were incubated in a humidified chamber at $55{ }^{\circ} \mathrm{C}$, and readings of the rate of colour development were taken after 24, 48 and $72 \mathrm{~h}$ (Viti \& Giovannetti, 2005). Results of the phenotypic characterization tests are given in the species description and in Table 1.

The partial 16S rRNA gene sequences of strains MP1, MP2 and MP3 as well the almost-complete sequence of strain $\mathrm{MP}^{\mathrm{T}}$ were reported previously by Bargagli et al. (2004). For the present study, more complete sequences of the $16 \mathrm{~S}$ rRNA gene of strains MP1, MP2 and MP3 were determined. By comparing 16S rRNA gene sequences between positions 36 and 1490 (Escherichia coli numbering system), strains MP1, MP3 and MP4 ${ }^{\mathrm{T}}$ showed $100 \%$ identity to each other, while strain MP2 differed from the other three at one nucleotide position. The four $16 \mathrm{~S}$ rRNA gene sequences were then used to retrieve closely matching type sequences at the Ribosomal Database Project (Cole et al., 2003). Phylogenetic analysis was performed by using the software package TREECON for Windows (Van de Peer \& De Wachter, 1997) after multiple alignment of the data by CLUSTAL_X (Thompson et al., 1997). Distances were converted to evolutionary distances according to the Jukes and Cantor method, and clustering with the neighbour-joining method was determined by using bootstrap values based on 1000 replications (Fig. 1). The $16 \mathrm{~S}$ rRNA gene sequence of strain $\mathrm{MP} 4^{\mathrm{T}}$ was a continuous stretch of $1505 \mathrm{bp}$. After a neighbour-joining analysis, 16S rRNA gene sequence similarity calculations indicated that the closest relatives of strain $\mathrm{MP} 4^{\mathrm{T}}$ were the type strains of A. pomorum (91.0\%), A. sacchari (90.9\%), A. hesperidum and A. macrosporangiidus (90.8\%), A. acidoterrestris (90.7\%) and A. cycloheptanicus (90.6\%). Lower sequence similarities $(<90.5 \%)$ were found with the type strains of all other recognized species of the genus.

GC analysis of methylated fatty acids was performed following the analytical procedures described by Kämpfer \& Kroppenstedt (1996). Analysis of the fatty acids at the conditions applied revealed that strain $\mathrm{MP}^{\mathrm{T}}$ was dominated by iso-branched fatty acids iso- $\mathrm{C}_{15: 0}(45.56 \%)$ and iso- $\mathrm{C}_{17: 0}(35.81 \%)$. In addition, smaller amounts of anteiso-branched fatty acids were found (anteiso- $\mathrm{C}_{15: 0}$, $6.4 \%$; anteiso- $\mathrm{C}_{17: 0}, 3.36 \%$ ). The DNA base composition for $\mathrm{MP}^{\mathrm{T}}$, determined according to the method of Mesbah et al. (1989), was $55.1 \mathrm{~mol} \% \mathrm{G}+\mathrm{C}$, which is within the range reported for recognized Alicyclobacillus species (48.7$62.7 \mathrm{~mol} \%$ ) (Goto et al., 2003; Karavaiko et al., 2005).

On the basis of the data presented, we conclude that strains MP1, MP2, MP3 and MP4 ${ }^{\mathrm{T}}$ represent a single novel species of the genus Alicyclobacillus, for which the name Alicyclobacillus pohliae sp. nov. is proposed.

\section{Description of Alicyclobacillus pohliae sp. nov.}

Alicyclobacillus pohliae (poh'li.ae. N.L. gen. fem. n. pohliae of Pohlia, a genus of moss colonizing the area where the type strain was isolated). 


\section{Table 1. Phenotypic characteristics of strain $\mathrm{MP}^{\top}$ and recognized species of the genus Alicyclobacillus}

Strains: $1, \mathrm{MP}^{\mathrm{T}}$ (data from the present study); 2, A. tolerans DSM $16297^{\mathrm{T}} ; 3$, A. disulfidooxidans DSM $12064^{\mathrm{T}}$ (data in columns 2 and 3 from Karavaiko et al., 2005); 4, A. acidocaldarius subsp. acidocaldarius ATCC $27009^{\mathrm{T}} ; 5$, A. acidoterrestris ATCC $49025^{\mathrm{T}} ; 6$, A. cycloheptanicus DSM $4006^{\mathrm{T}}$ (data in columns 4-6 from Goto et al., 2007); 7, A. hesperidum DSM 12489 ${ }^{\mathrm{T}}$ (Albuquerque et al., 2000); 8, A. acidiphilus TA67 ${ }^{\mathrm{T}}$ (Matsubara et al., 2002); 9, A. herbarius $\mathrm{CP}^{\mathrm{T}}$ (Goto et al., 2002); 10, A. pomorum $3 \mathrm{~A}^{\mathrm{T}}$ (Goto et al., 2003); 11, A. sendaiensis NTAP-1 ${ }^{\mathrm{T}}$ (Tsuruoka et al., 2003); 12, A. vulcanalis DSM $16176^{\mathrm{T}}$ (Simbahan et al., 2004); 13, A. sacchari $\mathrm{RB} 718^{\mathrm{T}}$; 14, A. fastidiosus S-TAB ${ }^{\mathrm{T}}$; 15, A. kakagawensis $5-\mathrm{A} 83 \mathrm{~J}^{\mathrm{T}}$; 16 , A. shizuokensis $4-$ A336 ${ }^{\mathrm{T}}$; 17, A. macrosporangiidus 5-A239-2O-A ${ }^{\mathrm{T}} ; 18$, A. contaminans 3-A191 (data in columns 13-18 from Goto et al., 2007). +, Positive; -, negative; $\mathrm{W}$, weakly positive; $\mathrm{V}$, variable between strains; NR, not reported. All strains produce acid from glucose.

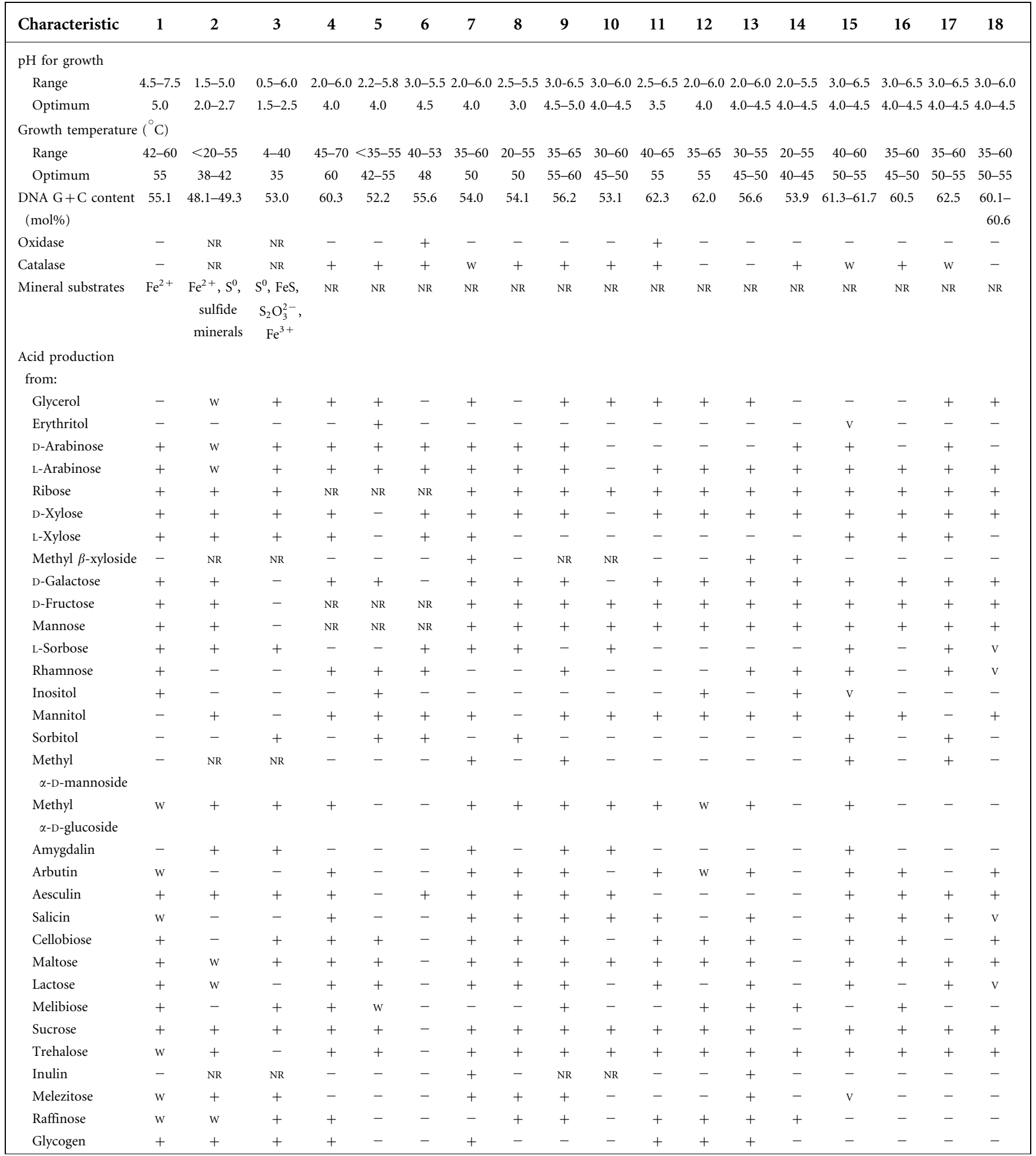


Table 1. cont.

\begin{tabular}{|c|c|c|c|c|c|c|c|c|c|c|c|c|c|c|c|c|c|c|}
\hline Characteristic & 1 & 2 & 3 & 4 & 5 & 6 & 7 & 8 & 9 & 10 & 11 & 12 & 13 & 14 & 15 & 16 & 17 & 18 \\
\hline Xylitol & - & NR & NR & - & + & - & - & + & - & - & - & - & - & - & + & - & + & - \\
\hline Gentiobiose & + & NR & NR & - & - & - & w & + & + & - & - & - & + & - & + & + & + & $\mathrm{v}$ \\
\hline Turanose & + & $\mathrm{w}$ & - & - & - & - & + & + & + & + & + & + & + & - & + & - & - & - \\
\hline D-Lyxose & + & NR & NR & - & - & + & + & - & - & - & - & - & - & + & + & - & + & - \\
\hline D-Tagatose & + & $\mathrm{w}$ & + & - & - & + & + & - & - & + & - & - & - & + & $\mathrm{v}$ & - & - & $\mathrm{v}$ \\
\hline D-Fucose & + & - & + & - & - & - & + & - & + & - & - & - & - & + & - & - & - & - \\
\hline L-Fucose & + & NR & NR & - & - & - & + & - & NR & NR & - & - & - & + & - & - & - & - \\
\hline D-Arabitol & - & NR & NR & - & - & - & + & - & NR & - & - & - & - & - & + & - & + & - \\
\hline 5-Ketogluconate & + & + & + & - & - & + & + & - & + & + & - & $\mathrm{w}$ & - & - & - & - & - & + \\
\hline
\end{tabular}

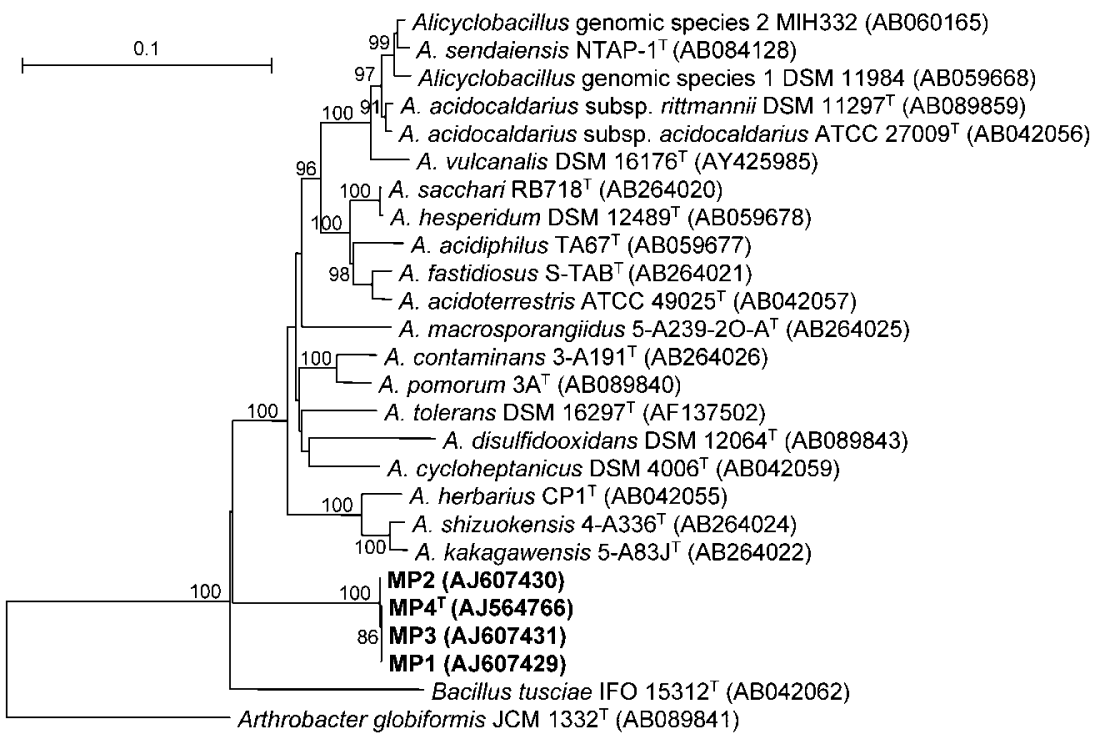

Fig. 1. Phylogenetic tree (constructed according to the neighbour-joining method) showing the position of the four novel strains in relation to recognized species of the genus Alicyclobacillus and a phylogenetically related Bacillus species, based on 16S rRNA gene sequences. Numbers represent percentages from 1000 replicate bootstrap samplings (values $<80 \%$ not shown). Arthrobacter globiformis JCM $1332^{\top}$ served as an outgroup. Bar, genetic divergence of 0.1 .

Aerobic, Gram-positive, spore-forming rods measuring $1.5-2.5 \times 0.4-0.6 \mu \mathrm{m}$. Round spores lie terminally in swollen sporangia. Oxidase- and catalase-negative. Does not grow in the presence of $5 \% \mathrm{NaCl}$. Colonies are creamcoloured, entire and convex and grow to $1.5-2 \mathrm{~mm}$ in diameter after $48 \mathrm{~h}$ at $55{ }^{\circ} \mathrm{C}$ in TSA-Fe. Iso-branched fatty acids iso- $\mathrm{C}_{15: 0}(45.56 \%)$ and iso- $\mathrm{C}_{17: 0}(35.81 \%)$ are the major cellular fatty acids. Facultatively anaerobic. Optimal growth occurs aerobically at $55{ }^{\circ} \mathrm{C}$ (range $42-60{ }^{\circ} \mathrm{C}$ ) and at pH 5.5 (range pH 4.5-7.5). Growth on yeast extract $(0.01 \%)$ occurs in the presence of ferrous iron $\left(\mathrm{Fe}^{2+}\right)$ at micromolar concentrations. Sensitive to $\left(\mathrm{ml}^{-1}\right)$ ampicillin $(25 \mu \mathrm{g})$, chloramphenicol $(10 \mu \mathrm{g})$, tetracycline $(50 \mu \mathrm{g})$, gentamicin $(30 \mu \mathrm{g})$, penicillin $\mathrm{G}(25 \mu \mathrm{g})$, bacitracin $(10 \mu \mathrm{g})$, erythromycin $(5 \mu \mathrm{g})$, kanamycin $(30 \mu \mathrm{g})$ and streptomycin $(25 \mu \mathrm{g})$. Acid is produced from D- and L-arabinose, ribose, D- and L-xylose, D-galactose, glucose, D-fructose, mannose, L-sorbose, rhamnose, inositol, $\mathrm{N}$ acetylglucosamine, aesculin, D-cellobiose, maltose, lactose, melibiose, sucrose, glycogen, gentiobiose, D-turanose,
D-lyxose, D-tagatose, D- and L-fucose and 2- and 5ketogluconate. Oxidizes D-xylose, D-ribose, $\alpha$-ketovaleric acid, L-proline and pyruvic acid methyl ester. The DNA $\mathrm{G}+\mathrm{C}$ content is $55.1 \mathrm{~mol} \%$.

The type strain, $\mathrm{MP}^{\mathrm{T}}\left(=\mathrm{CIP} 109385^{\mathrm{T}}=\mathrm{NCIMB} 14276^{\mathrm{T}}\right)$, was isolated from geothermal soil on the north-west slope of Mount Melbourne on the Antarctic continent. Strains MP1, MP2 and MP3, isolated from the same vicinity, are also included in the species.

\section{Acknowledgements}

We thank H. G. Trüper for advice on nomenclatural etymology. This work was partially supported by the University of Siena (PAR).

\section{References}

Albuquerque, L., Rainey, F. A., Chung, A. P., Sunna, A., Nobre, M. F., Grote, R., Antranikian, G. \& De Costa, M. S. (2000). Alicyclobacillus 
hesperidum sp. nov. and a related genomic species from solfataric soils of São Miguel in the Azores. Int J Syst Evol Microbiol 50, 451-457.

Allan, R. N., Lebbe, L., Heyrman, J., De Vos, P., Buchanan, C. J. \& Logan, N. A. (2005). Brevibacillus levickii sp. nov. and Aneurinibacillus terranovensis sp. nov., two novel thermoacidophiles isolated from geothermal soils of northern Victoria Land, Antarctica. Int J Syst Evol Microbiol 55, 1039-1050.

Bargagli, R., Skotnicki, M. L., Marri, L., Pepi, M., Mackenzie, A. \& Agnorelli, C. (2004). New record of moss and thermophilic bacteria species and physico-chemical properties of geothermal soils on the northwest slope of Mt. Melbourne (Antarctica). Polar Biol 27, 423-431.

Cole, J. R., Chai, B., Marsh, T. L., Farris, R. J., Wang, Q., Kulam, S. A., Chandra, S., McGarrell, D. M., Schmidt, T. M. \& other authors (2003). The Ribosomal Database Project (RDP-II): previewing a new autoaligner that allows regular updates and the new prokaryotic taxonomy. Nucleic Acids Res 31, 442-443.

Deinhard, G., Saar, J., Krischke, W. \& Poralla, K. (1987). Bacillus cycloheptanicus sp. nov., a new thermophile containing $\omega$-cycloheptane fatty acids. Syst Appl Microbiol 10, 68-73.

Goto, K., Matsubara, H., Mochida, K., Matsumura, T., Hara, Y., Niwa, M. \& Yamasato, K. (2002). Alicyclobacillus herbarius sp. nov., a novel bacterium containing omega-cycloheptane fatty acids, isolated from herbal tea. Int J Syst Evol Microbiol 52, 109-113.

Goto, K., Mochida, K., Asahara, M., Suzuki, M., Kasai, H. \& Yokota, A. (2003). Alicyclobacillus pomorum sp. nov., a novel thermo-acidophilic, endospore-forming bacterium that does not possess $\omega$-alicyclic fatty acids, and emended description of the genus Alicyclobacillus. Int J Syst Evol Microbiol 53, 1537-1544.

Goto, K., Mochida, K., Kato, Y., Asahara, M., Fujita, R., An, S. Y., Kasai, H. \& Yokota, A. (2007). Proposal of six species of moderately thermophilic, acidophilic, endospore-forming bacteria: Alicyclobacillus contaminans sp. nov., Alicyclobacillus fastidiosus sp. nov., Alicyclobacillus kakegawensis sp. nov., Alicyclobacillus macrosporangiidus sp. nov., Alicyclobacillus sacchari sp. nov. and Alicyclobacillus shizuokensis sp. nov. Int J Syst Evol Microbiol 57, 1276-1285.

Hiraishi, A., Inagaki, K., Tanimoto, Y., Iwasaki, M., Kishimoto, N. \& Tanaka, H. (1997). Phylogenetic characterization of a new thermoacidophilic bacterium isolated from hot springs in Japan. J Gen Appl Microbiol 43, 295-304.

Kämpfer, P. \& Kroppenstedt, R. M. (1996). Numerical analysis of fatty acid patterns of coryneform bacteria and related taxa. Can J Microbiol 42, 989-1005.

Karavaiko, G. I., Bogdanova, T. I., Tourova, T. P., Kondrat'eva, T. F., Tsaplina, I. A., Egorova, M. A., Krasil'nikova, E. N. \& Zakharchuk, L. M. (2005). Reclassification of 'Sulfobacillus thermosulfidooxidans subsp. thermotolerans' strain $\mathrm{K} 1$ as Alicyclobacillus tolerans sp. nov. and Sulfobacillus disulfidooxidans Dufresne et al. 1996 as Alicyclobacillus disulfidooxidans comb. nov., and emended description of the genus Alicyclobacillus. Int J Syst Evol Microbiol 55, 941-947.

Logan, N. A., Lebbe, L., Hoste, B., Goris, J., Forsyth, G., Heyndrick, M., Murray, B. L., Syme, N., Wynn-Williams, D. D. \& De Vos, P. (2000). Aerobic endospore-forming bacteria from geothermal environments in northern Victoria Land, Antarctica, and Candlemas Island, South
Sandwich Archipelago, with the proposal of Bacillus fumarioli sp. nov. Int J Syst Evol Microbiol 50, 1741-1753.

Matsubara, H., Goto, K., Matsumura, T., Mochida, K., Iwaki, M., Niwa, M. \& Yamasato, K. (2002). Alicyclobacillus acidiphilus sp. nov., a novel thermo-acidophilic, $\omega$-alicyclic fatty acid-containing bacterium isolated from acidic beverages. Int J Syst Evol Microbiol 52, 1681-1685.

Mesbah, M., Premachandran, U. \& Whitman, W. B. (1989). Precise measurement of the $\mathrm{G}+\mathrm{C}$ content of deoxyribonucleic acid by highperformance liquid chromatography. Int J Syst Bacteriol 39, 159-167.

Nicolaus, B., Lama, L., Esposito, E., Manca, M. C., Di Prisco, G. \& Gambacorta, A. (1996). "Bacillus thermoantarcticus" sp. nov., from Mount Melbourne, Antarctica: a novel thermophilic species. Polar Biol 16, 101-104.

Nicolaus, B., Improta, R., Manca, M. C., Lama, L., Esposito, E. \& Gambacorta, A. (1998). Alicyclobacilli from an unexplored geothermal soil in Antarctica: Mount Rittmann. Polar Biol 19, 133-141.

Poli, A., Esposito, E., Lama, L., Orlando, P., Nicolaus, G., de Appolonia, F., Gambacorta, A. \& Nicolaus, B. (2006). Anoxybacillus amylolyticus sp. nov., a thermophilic amylase producing bacterium isolated from Mount Rittmann (Antarctica). Syst Appl Microbiol 29, 300-307.

Powers, E. M. (1995). Efficacy of the Ryu nonstaining $\mathrm{KOH}$ technique for rapidly determining gram reactions of food-borne and waterborne bacteria and yeasts. Appl Environ Microbiol 61, 3756-3758.

Simbahan, J., Drijber, R. \& Blum, P. (2004). Alicyclobacillus vulcanalis sp. nov., a thermophilic, acidophilic bacterium isolated from Coso Hot Springs, California, USA. Int J Syst Evol Microbiol 54, 1703-1707.

Smibert, R. M. \& Krieg, N. R. (1981). General characterization. In Manual of Methods for General Bacteriology, pp. 411-442. Edited by P. Gerhardt, R. G. E. Murray, R. N. Costilow, E. W. Nester, W. A. Wood, N. R. Krieg \& G. B. Philips. Washington, DC: American Society for Microbiology.

Thompson, J. D., Gibson, T. J., Plewniak, F., Jeanmougin, F. \& Higgins, D. G. (1997). The CLUSTAL_X windows interface: flexible strategies for multiple sequence alignment aided by quality analysis tools. Nucleic Acids Res 25, 4876-4882.

Tsuruoka, N., Isono, Y., Shida, O., Hemmi, H., Nakayama, T. \& Nishino, T. (2003). Alicyclobacillus sendaiensis sp. nov., a novel acidophilic, slightly thermophilic species isolated from soil in Sendai, Japan. Int J Syst Evol Microbiol 53, 1081-1084.

Van de Peer, Y. \& De Wachter, R. (1997). Construction of evolutionary distance trees with TREECON for Windows: accounting for variation in nucleotide substitution rate among sites. Comput Appl Biosci 13, 227-230.

Viti, C. \& Giovannetti, L. (2005). Characterization of cultivable heterotrophic bacterial communities in Cr-polluted and unpolluted soils using Biolog and ARDRA approaches. Appl Soil Ecol 28, 101-112.

Wisotzkey, J. D., Jurtshuk, P., Jr, Fox, G. E., Deinhard, G. \& Poralla, K. (1992). Comparative sequence analyses on the 16S rRNA (rDNA) of Bacillus acidocaldarius, Bacillus acidoterrestris, and Bacillus cycloheptanicus and proposal for creation of a new genus, Alicyclobacillus gen. nov. Int J Syst Bacteriol 42, 263-269. 